\title{
Activity patterns of frugivorous phyllostomid bats in an urban fragment in southwest Amazonia, Brazil
}

\author{
Rair S. Verde ${ }^{2}$, Richarlly C. Silva² \& Armando M. Calouro ${ }^{12}$
}

\begin{abstract}
1. Universidade Federal do Acre, Programa de Pós-Graduacão em Ecologia e Manejo de Recursos Naturais, Rio Branco, AC, Brazil. (rair.verde@gmail.com) 2. Universidade Federal do Acre, Laboratório de Ecologia de Mamíferos, BR-364, Km 4, Distrito Industrial, 69902-350, Rio Branco, AC, Brazil.
\end{abstract}

Received 12 January 2018

Accepted 11 April 2018

Published 11 June 2018

DOI 10.1590/1678-4766e2018016

ABSTRACT. The habitat fragmentation modifies the pattern of animal activity. This study aimed to determine the activity pattern of frugivorous bat species in an urban forest fragment in southwestern Amazonia. The study was conducted from August 2013 to September 2014 with 10 mist nets $(9 \mathrm{~m}$ x $2.5 \mathrm{~m}$ ), opened at ground level throughout all the night and totaling $64,800 \mathrm{~m}^{2}$.hour/net. Two hundred and sixty-one captures of bats from 28 species were recorded. The period with the highest capture rate and species of bats was the first period of the night (until 00:00). The species with the highest incidence of catches were, in ascending order, Carollia brevicauda (Schinz, 1821), Carollia perpicillata (Linnaeus, 1758), Artibeus planirostris (Spix, 1823), and Artibeus lituratus (Olfers, 1818). The species of Carollia had activity peaks between the first four hours after sunset; they also showed a reduction of its activities during the subsequent hours. The bats of the genus Artibeus presented a pattern of bimodal activity and they do not seem to respond to the effects of fragmentation, since the pattern of bimodal activity was described for studies in fragments and continuous forest. Thus, we suggest that Artibeus has a high adaptive plasticity, and it is able to exploit the resources offered by the environment. Meanwhile, Carollia has two peaks of activity in continuous forest areas, probably this pattern of activity may be related to the spatial distribution of the resources used by these animals.

KEYWORDS. Amazon forest, forest fragmentation, fruit-eating, pattern hourly activity, Phyllostomidae.

Bats are the second largest order of mammals (VOIGT \& Kingston, 2016), and the Phyllostomidae are the most diverse family among Neotropical bats (KALKO, 1998). The phyllostomids cover various types of trophic interactions; they are a key group in seed dispersal (GIANNINI \& KaLKO, 2004 ), in pollination and predation, and controlling a wide variety of prey (Kunz \& Fenton, 2003). Some of these bats are active in pollination and seed dispersal of many pioneer and understory plants (KunZ et al., 2011). According to Bowen et al. (2007), the success of the restoration of perturbed areas is directly linked to the populations of these animals, because frugivorous bats have a preference to eating away from the mother plant. This increase the likelihood of germination and establishment of seeds (Levin et al., 2003).

Bats exhibit a variety of behavioral, morphological, and physiological adaptations for foraging, which are expressed by their habits and influencing their temporal activity patterns (SChnitZler \& Kalko, 2001). This is evident when the morphology of bats that have different feeding niches and relatively distinct foraging times is compared (SCHNITZLER \& KalKo, 2001; KalKa \& KalKo, 2006). Thus, the availability and spatial-temporal distribution of resources, and even the type of foraging and body mass of bats, act as factors that determine the pattern of activity of each species (WEINBEER et al., 2006). The patterns can be unimodal, bimodal, or even without pronounced peaks (WEINBEER et al., 2006).
The phyllostomids bats usually have a standard unimodal activity, with a decrease of the activities from the first hour after sunset (CHARLES-DOMINIQUE, 1991; BERNARD \& Fenton, 2002). This pattern may vary according to the availability of ripe fruit (THIES \& KALKO, 2004). In contrast, species of insectivorous and carnivorous bats, which consume constant resources, often exhibit a pattern of activity without pronounced peaks (KALKO et al., 1999; WeINBEER \& KALKO, 2004; WeINBEER et al., 2006).

The pattern of activity is crucial for understanding the behavior of these animals, which actively seek sex partners, compete for resources, and avoid predators (THIEs et al., 2006). Moreover, bats may also be sensitive to habitat fragmentation (PIRES et al., 2006). However, according to KALKO \& HANDLEY (2001), in environments that require greater locomotion capability (e.g. pastures, roads, and secondary forests), bats are less sensitive to fragmentation due to their great mobility, than species with limited dispersion. Thus, the foraging activity is influenced by the availability of resources, climatic conditions, the risk of predation, the physical condition of the animal, and the reproductive status (THIEs et al., 2006). These factors, singly or in combination, limit the foraging activity of bats. In addition to the environmental and biological factors, activity patterns have strong phylogenetic constraints (KRONFELD-SCHOR \& DAYAN, 2003), that determine the foraging activity of the species during 
the night. Moreover, any change in the activity, in response to disturbances and seasonal or habitat physiognomy, modifies the temporal niche of these species and increases the level of competition between them (PRESLEY et al., 2009).

We aim to examine the pattern of temporal and seasonal activity of Phyllostomidae frugivorous bats of an urban forest fragment in southwestern Amazonia from two perspectives. First, we examined the differences in hourly activity throughout the night, considering the abundance of each species. Second, we evaluated if these species modify their activity pattern in response to seasonality.

\section{MATERIALS AND METHODS}

Study area. The study was conducted at the Parque Zoobotânico (PZ) in the city of Rio Branco, state of Acre, northern Brazil, Amazon (9॰57'26”'S, 6752’25’W) (Fig. 1). The area comprises an urban forest fragment of approximately 135 ha. The climate of the region according to Am the Köppen (Alvares et al., 2013) is hot and humid, with annual minimum temperature around $24^{\circ} \mathrm{C}$ and two distinct seasons: dry, from May to September; and rainy, from October to April (MACEDo et al., 2013). During the study period, the average temperature was $23.4^{\circ} \mathrm{C}$ and the cumulative precipitation was $2,412.5 \mathrm{~mm}$; July 2014 was the driest month (12.2 $\mathrm{mm})$ and January 2014 was the rainiest one $(462.2 \mathrm{~mm})$ (INMET, 2015). The vegetation of the PZ is formed by mosaic vegetation in different successional stages, with inconspicuous transitions in its plant structure and floristic composition (CALOURo et al., 2010). Moreover, a presence of bamboo of the genus Guadua (Bamboideae: Poaceae), common in the southwest of the Amazon (CARVALHo et al., 2013), affects forest structure and tree diversity (SILVEIRA, 2005). Thus, the population dynamics of bamboo provided the formation of three basic types of vegetation in the PZ: open rain forest with palm trees, open rain forest with more bamboo than palm trees, and open rain forest with bamboo (CAlouro et al., 2010). Another important feature of the PZ is the surrounding matrix, which consists of pastures and, mainly, houses of two neighborhoods in Rio Branco.

Data sampling. Samples were performed from August 2013 to September 2014, two nights each month, with a total of 24 sampling nights. Twelve of these nights were held during the dry season and the other 12 in the wet season to evaluate the effect of seasonality. Every night, 10 mist nets $(9 \mathrm{~m} \mathrm{x} 2.5 \mathrm{~m})$ were placed at the ground level, kept open for 12 hours, and checked every 15 minutes. The total sampling effort was $64,800 \mathrm{~m}^{2}$ hour/net. The captured bats were placed in cotton bags to collect the following data: species, sex, age, reproductive condition, and body weight. The bats were identified according to the keys of SimMONS (2005), GARDNER (2007), and DiAz et al. (2011), and then classified into trophic guilds, as proposed by

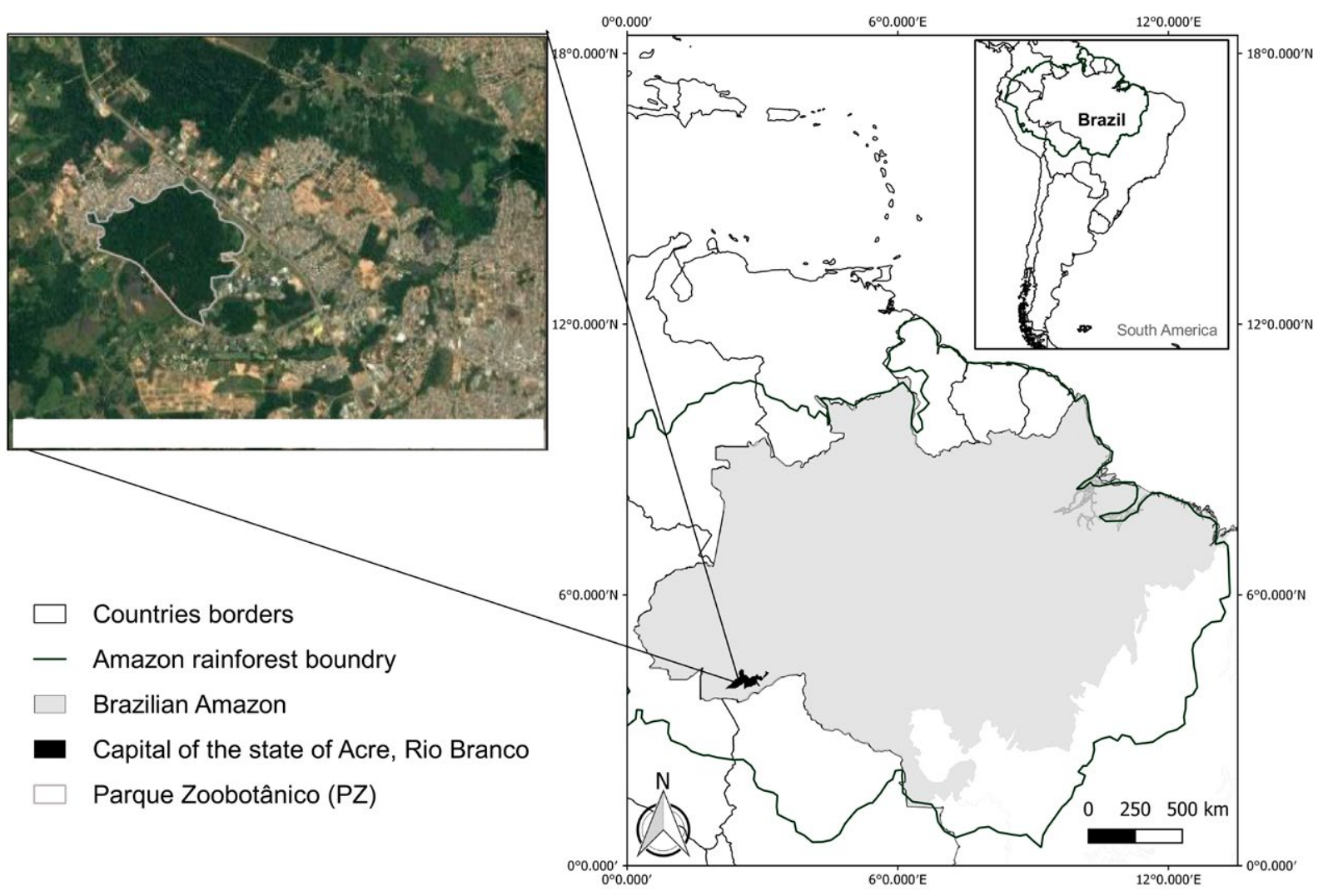

Fig. 1. Location of the forest fragment (Parque Zoobotânico) in the urban area of Rio Branco, Acre, southwestern Amazonia, Brazil. 
Simmons \& Voss (1998). After identification, the individuals were released at the collection site after the closing of the nets. When the identification was not possible in field, the specimens were euthanized and identified in the laboratory through craniometrics and dentition features. Then, they were deposited as voucher specimen at the Mammals of Zoological Collection of the Universidade Federal do Acre.

Statistical analysis. The comparative analyzes were performed using the data capture of Phyllostomidae bats, because according to ReIs et al. (2000) using mist nets promotes a greater number of catches of individuals from this family. To compare the temporal pattern and seasonal activities of the frugivorous species, we restrict the analysis for the species with more than ten captures. To compare the level of activity between the first and the second half of the night of the four most abundant species, we used the Mann-Whitney test. This test was also used to compare the species richness between the first and the second half of the night. We compared the abundance distributions of the most captured genera in the two halves of the night with the Kolmogorov-Smirnov test. In addition, we compared the abundance of Carollia and Artibeus according to precipitation using the Mann-Whitney test. All data were analyzed using the BioEstat 5.0.

\section{RESULTS}

Two hundred and sixty-one specimens of 28 species of bats were recorded belonging to 20 genera and four families. Among the total, $69.4 \%$ of individuals were captured from 18:00 to $00: 00$, and $30.6 \%$ in the period from 00:00 to 06:00. The period $\leq 0: 00$ showed a greater species richness $(n=23)$ than $\geq 0: 01$ period $(\mathrm{n}=12)$. The species with the highest capture rates were Artibeus lituratus $(\mathrm{n}=78)$, A. planirostris $(\mathrm{n}=60)$, Carollia perspicillata $(\mathrm{n}=42)$, and $C$. brevicauda $(\mathrm{n}=31)$ (Tab. I). Regarding trophic guilds, the frugivorous were the most abundant ( $85.1 \%$ of the total captures), followed by omnivorous (10.7\%) and nectarivorous (4.2\%).

Tab. I. List of bat species recorded in the Parque Zoobotânico (PZ) in two periods after sunset ( $\leq$ 00:00 $\mathrm{h}$ and $\geq 00: 01 \mathrm{~h})$. The number of individuals and the percentage of the total captures (T) are indicated. Guild ranking $(\mathrm{G})$ as Simmons \& Voss (1998): FR, frugivorous; NE, nectarivorous; IN, insectivorous; CA, carnivorous; ON, omnivorous. The new records for the state of Acre are indicated with *

\begin{tabular}{|c|c|c|c|c|c|}
\hline $\begin{array}{l}\text { Family } \\
\text { Subfamily } \\
\text { Species } \\
\end{array}$ & G & $\leq 00: 00 \mathrm{~h}$ & $\geq 00: 01 \mathrm{~h}$ & $\mathrm{~T}$ & $\%$ \\
\hline \multicolumn{6}{|l|}{ Emballonuridae } \\
\hline Saccopteryx canescens Thomas, 1901* & In & 3 & 0 & 3 & 0.4 \\
\hline Saccopteryx leptura (Schreber, 1774) & In & 1 & 0 & 1 & 1.1 \\
\hline \multicolumn{6}{|l|}{ Molossidae } \\
\hline Molossus molossus (Pallas, 1766) & In & 0 & 1 & 1 & 0.4 \\
\hline \multicolumn{6}{|l|}{ Phyllostomidae } \\
\hline \multicolumn{6}{|l|}{ Carolliinae } \\
\hline Carollia perspicillata (Linnaeus, 1758) & Fr & 35 & 7 & 42 & 16.1 \\
\hline Carollia brevicauda $($ Schinz, 1821) & $\mathrm{Fr}$ & 25 & 6 & 31 & 11.5 \\
\hline \multicolumn{6}{|l|}{ Glossophaginae } \\
\hline Anoura caudifer (É. Geoffroy Saint-Hilaire, 1818) & $\mathrm{Ne}$ & 0 & 1 & 1 & 0.4 \\
\hline Glossophaga soricina (Pallas, 1766) & $\mathrm{Ne}$ & 3 & 4 & 7 & 3.0 \\
\hline Glossophaga sp. & $\mathrm{Ne}$ & 2 & 0 & 2 & 0.8 \\
\hline \multicolumn{6}{|l|}{ Hsunycterinae } \\
\hline Hsunycteris thomasi (J. A. Allen, 1904) & $\mathrm{Ne}$ & 0 & 1 & 1 & 0.4 \\
\hline \multicolumn{6}{|l|}{ Micronycterinae } \\
\hline Micronycteris megalotis (Gray, 1842) & In & 0 & 1 & 1 & 0.4 \\
\hline Micronycteris microtis Miller, 1898* & In & 1 & 0 & 1 & 0.4 \\
\hline Lophostoma silvicola d'Orbigny, 1836 & In & 3 & 0 & 3 & 1.1 \\
\hline Lophostoma brasiliense Peters, $1866^{*}$ & In & 2 & 0 & 2 & 0.8 \\
\hline Mimon crenulatum (É. Geoffroy, 1803) & In & 1 & 0 & 1 & 0.4 \\
\hline Phyllostomus elongatus (É. Geoffroy, 1810) & On & 7 & 3 & 10 & 4.0 \\
\hline Phyllostomus hastatus (Pallas, 1767) & On & 2 & 0 & 2 & 0.8 \\
\hline Tonatia saurophila Koopman E Williams, 1951 & In & 1 & 0 & 1 & 0.4 \\
\hline \multicolumn{6}{|l|}{ Stenodermatinae } \\
\hline Artibeus lituratus (Olfers, 1818) & $\mathrm{Fr}$ & 41 & 37 & 78 & 30 \\
\hline Artibeus obscurus (Schinz, 1821) & $\mathrm{Fr}$ & 1 & 0 & 1 & 0.4 \\
\hline Artibeus planirostris (Spix, 1823) & $\mathrm{Fr}$ & 45 & 15 & 60 & 23 \\
\hline Chiroderma trinitatum Goodwin, 1958 & $\mathrm{Fr}$ & 1 & 0 & 1 & 0.4 \\
\hline Dermanura cinerea Gervais, 1856 & $\mathrm{Fr}$ & 2 & 0 & 2 & 0.8 \\
\hline Platyrrhinus brachycephalus (Rouk E Carter, 1972) & $\mathrm{Fr}$ & 1 & 0 & 1 & 0.4 \\
\hline Platyrrhinus incarum (Thomas, 1912) & $\mathrm{Fr}$ & 1 & 0 & 1 & 0.4 \\
\hline Platyrrhinus infuscus (Peters, 1880) & $\mathrm{Fr}$ & 1 & 0 & 1 & 0.4 \\
\hline
\end{tabular}


Tab. I. Cont.

\begin{tabular}{|c|c|c|c|c|c|}
\hline \multicolumn{6}{|l|}{ Family } \\
\hline Subfamily & G & $\leq 00: 00 \mathrm{~h}$ & $\geq 00: 01 \mathrm{~h}$ & $\mathrm{~T}$ & $\%$ \\
\hline \multicolumn{6}{|l|}{ Species } \\
\hline Sturnira lilium (Thomas, 1912) & $\mathrm{Fr}$ & 1 & 1 & 2 & 0.8 \\
\hline Uroderma bilobatum Peters, 1866 & Fr & 0 & 1 & 1 & 0.4 \\
\hline \multicolumn{6}{|l|}{ Vespertilionidae } \\
\hline Myotis riparius Handley, 1960 & In & 3 & 0 & 3 & 1.1 \\
\hline $\mathrm{N}^{o}$ individuals & & 183 & 78 & 261 & 100 \\
\hline
\end{tabular}

The abundance of frugivorous species did not differ along the night $(Z=1.4412, p=0.0748)$. For omnivorous, there was a significant difference between the first and second half of the night $(Z=1.8415, \mathrm{p}=0.0328)$.

The species of Carollia had peaks of activity between the first four hours after sunset and a posterior decrease of their activities during the subsequent hours. However, considering the level of activity between the first and second half of the night, there was no significant differences in the abundance of $C$. perspicillata $(\mathrm{Z}=0.5604, \mathrm{p}=0.2876)$ and C. brevicauda $(\mathrm{Z}=0.9608, \mathrm{p}=0.1683)$. On the other hand, Artibeus planirostris showed a bimodal pattern of activity, and its abundance differed between the two periods of the night (Fig. 2). With regards to A. lituratus, its pattern of activity did not differ between the first and second half of the night $(Z=2.3219, p=0.0101$ and $Z=0.9608, p=0.1683$, respectively).

Regarding seasonality, for both species of Carollia we did not registered significant differences among seasons ( $Z=1.0445, p=0.1481$ ), while for the species of Artibeus we observed a peak of captures during the dry period (Fig. 3). However, these differences were not statistically significant $(Z=1.0445, \mathrm{p}=0.1481)$.

\section{DISCUSSION}

Recent studies have observed the community of bats from Parque Zoobotânico (CALOURo et al., 2010; SANTOS et al., 2012), and obtained an abundance and species richness lower than our study. However, these differences were due to the highest sampling effort, temporal scales, and/or different experimental focus. CALOURO et al. (2010) evaluated variations in the richness and abundance of bats in response to the edge effect; this may have influenced the abundance of bats.

Seasonality does not seem to have influenced the bat capture rate in this study. The frugivorous species showed an uniform activity, with shorter intervals between peaks of activity. Carollia perspicillata and C. brevicauda showed a high peak of activity in the first four hours, maintaining an uniform foraging activity after the peak; then we observed a reduction of their activity on the rest of the night. This pattern is typical of a small frugivorous that goes through energetic stress, which forces an immediate search for food (Charles-Dominique, 1991). Bernard (2002), in a study on continuous forest in the Amazon, obtained similar results for the frugivorous species, but also registered two peaks of activity for Carollia, one at 19:00 and another at 01:00. The same pattern was observed by ORTÊNCIO-FILHO et al.
(2010) in three small fragments of Atlantic Forest with $C$. perspicillata, and THIES et al. (2006) on Barro Colorado Island in Panama with C. castanea as a result of high availability of resources. The large spatial distribution of resources consumed by Carollia in fragments and continuous forests can explain the differences observed between the studies on species of this genus.

For large frugivorous, as Artibeus lituratus and $A$. planirostris, we observed a peak of activity in the three hours after sunset (19:00 and 20:00 respectively) and an increase of activity near dawn, corresponding to the results found in other forest fragments by AGUIAR \& MARINHOFILHO (2004) and ORTÊNCIO-FILHO et al. (2010). In studies conducted in continuous forest, BERNARD (2002) observed a bimodal pattern for $A$. planirostris, which probably is a common feature of the species in continental regions. Moreover, CASTRO-ArEllano et al. (2009) found a high abundance of Artibeus in the early evening. Thus, the hourly activity of bats of this genus apparently tolerates the effects of fragmentation, suggesting that these bats have a high adaptive plasticity.

The temporal and seasonal activity of bats is closely linked to the dynamics and abundance of resources, climatic conditions, predation risk, physical condition, and reproductive animal stage (THIES et al., 2006). The abundance of Carollia perspicillata and C. brevicauda in the PZ does not seem to be affected by seasonal variation, as observed both in forest fragments and continuous forests (BERNARD, 2002; Aguiar \& MARINHO-FILHO, 2004; Thies et al., 2006; PRESLEY et al., 2009; ORTÊNCIO-FILHO et al., 2010). Species of this genus feed on fruits of pioneer plants, which are less seasonal, such as Piper (ORTÊNCIO-FILHO et al., 2014). On the other hand, the activity pattern of major frugivorous may change depending on the rainfall, because the fruiting peaks generally coincide with the highest levels of precipitation. In the Amazon, this event occurs in the plants of genus Ficus, which are more abundant during the rainy season and are commonly found in the canopy (FOSTER \& JANSON, 1985; Smythe, 1986; Pereira et al., 2010). Bats of Artibeus are very sensitive to seasonal variations of rainfall (MELLO, 2009). Artibeus lituratus and A. planirostris were captured over the months with low rainfall, probably because in the dry season when food supplies are scarce, they are forced to consume the understory plants with higher fruiting periods. This variation in the abundance of $A$. lituratus was also observed by other authors (AgUIAR \& MARINHO-FILHO, 2004; Presley et al., 2009; ORTÊNCIO-FilHo et al., 2010; Pereira et al., 2010; MANCINA \& CASTro-Arellano, 2013). 


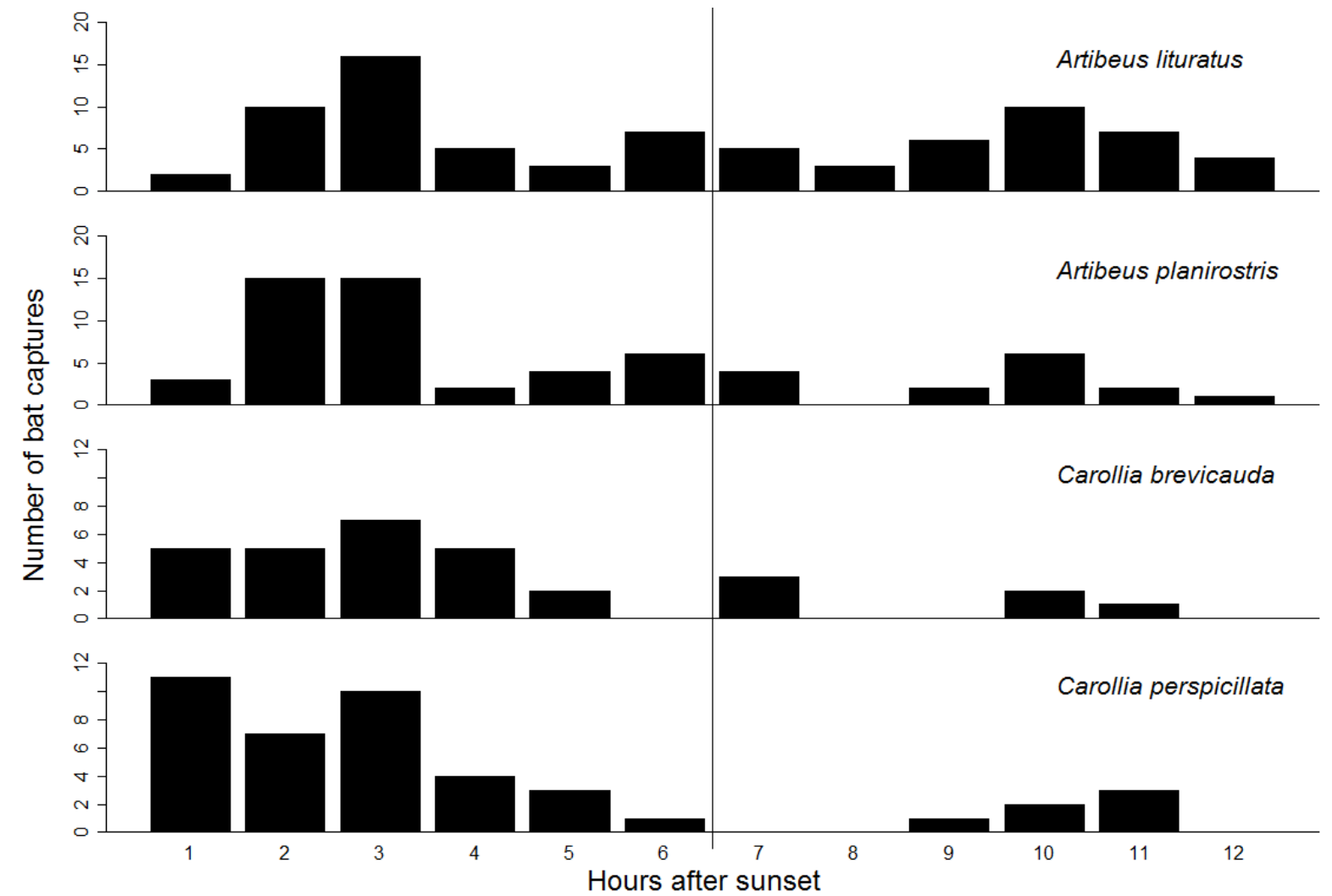

Fig . 2. Number of captures of the four most abundant species throughout the night period, according to hours after sunset, in the Parque Zoobotânico, Rio Branco, state of Acre, northern Brazil.
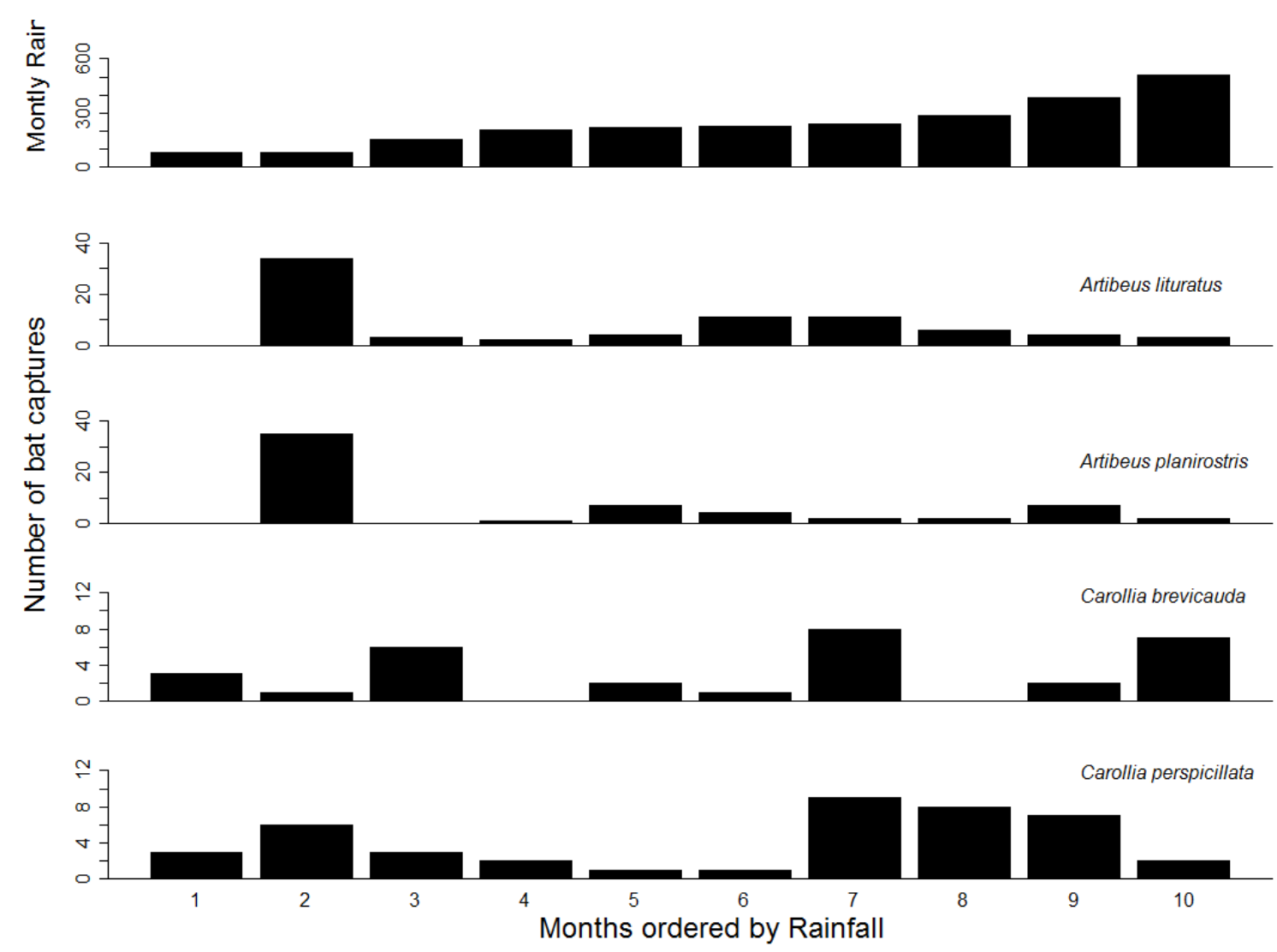

Fig. 3. Number of captures of the four most abundant species, according to the rainfall in the Parque Zoobotânico, Rio Branco, state of Acre, northern Brazil. 
Fragmentation of habitats is already a reality in the Brazilian Amazon. Understanding variations in the patterns of activity of the different species of bats is an essential step to define which have more or less adaptive plasticity to survive in this new landscape, in addition to supporting the management of these forest fragments and the recovery of the degraded areas.

Acknowledgments. We thank to the Conselho Nacional de Desenvolvimento Científico e Tecnológico (CNPq), and the people responsible for the Parque Zoobotânico da Universidade Federal do Acre for allowing the research in the study area. We also thank to the people who helped us in this study.

\section{REFERENCES}

Aguiar, L. M. S. \& Marinho-Filho, J. 2004. Diversity and habitat preference of medium and large-sized mammals in an urban forest fragment of southwestern Amazon. Revista Brasileira de Biologia 21(2):385-390.

Alvares, C. A.; Stape, J. L.; Sentelhas, P. C. M. G.; Leonardo, J. \& SparoveK, G. 2013. Köppen's climate classification map for Brazil. Meteorologische Zeitschrift 22(6):711-728.

BERNARD, E. 2002. Diet, activity and reproduction of bat species (Mammalia, Chiroptera) in central Amazonia, Brazil. Revista Brasileira de Biologia 19(1):173-188.

BERnARD, E \& FENTON, M. B. 2002. Species diversity of bats (Mammalia: Chiroptera) in forest fragments, primary forests, and savannas in central Amazonia, Brazil. Canadian Journal of Zoology 80(6):1124-1140.

Bowen, M. E.; Mcalpine, C. A.; House, A. P. N. \& Smith, G. C. 2007. Regrowth forests on abandoned agricultural land: a review of their habitat values for recovering forest fauna. Biology Conservation 140(3):273-296.

Calouro, A. M.; Santos, F. G. A.; Faustino, S. F.; Souza, S. F.; Lague, B. M.; Marciente, R.; Santos, G. J. L. \& CunHa, A. O. 2010. Riqueza e abundância de morcegos capturados na borda e no interior de um fragmento florestal do estado do Acre, Brasil. Biotemas 23(4):109-117.

Carvalho, A. L.; Nelson, B. W.; Bianchini, M. C.; Plagnol, D.; Kuplich, T. M. \& DALY, D. C. 2013. Bamboo-dominated forests of the southwest Amazon: Detection, spatial extent, life cycle length and flowering waves. Plos One 8(1):1-13.

Castro-Arellano I.; Presley, S. J.; Willig, M. R.; Wunderle, J. M. \& SALDANHA, L. N. 2009. Reduced-impact logging and temporal activity of understory bats in lowland Amazonia. Biological Conservation 142(10):2131-2139.

Charles-Dominique, P. 1991. Feeding strategy and activity budget of the frugivorous bat Carollia perspicillata (Chiroptera: Phyllostomidae) in French Guiana. Journal of Tropical Ecology 7(02):243-256

Díaz, M. M.; Aguirre, L. F. \& BARQuEZ, R. M. 2011. Clave de identificación de los murciélagos del cono sur de Sudamérica. Cochabamba, Centro de Estudios en Biología Teórica y Aplicada. 104p.

Foster, S. A. \& JANSON, C. H. 1985. The relationship between seed size and establishment conditions in tropical woody plants. Ecology 66(3):773-780

Gardner, A. L. 2007. Mammals of South America - Volume 1. Chicago, The University of Chicago Press. 690p.

Giannini, N. P. \& Kalko, E. K. V. 2004. Trophic structure in a large assemblage of phyllostomid bats in Panama. Oikos 105(2):209-220.

INMET - Instituto NaCional de Meteorologia. 2015. Banco de Dados Meteorológicos para Ensino e Pesquisa. Available at $<\mathrm{http}: / / \mathrm{www}$. inmet.gov.br/portal/index.php?r=bdmep/bdmep >.

KalKa, M. \& Kalko, E. K. V. 2006. Gleaning bats as underestimated predators of herbivorous insects: dietary composition of Micronycteris microtis (Phyllostomidae) in Panamá. Journal of Tropical Ecology 22(01):1-10.

KALKO, E. K. V. 1998. Organization and diversity of tropical bat communities through space and time. Zoology 101(4):281-297.

KALKO, E. K. V. \& HANDLEY JR, C. O. 2001. Neotropical bats in the canopy: diversity, community structure, and implications for conservation. Plant Ecology 153(1-2):319-333.
Kalko, E. K. V.; Krull, D.; Handley Jr, C. O. \& Schnitzler, H. U. 1999. Roosting and foraging behavior of two Neotropical gleaning bats, Tonatia silvicola and Trachops cirrhosus (Phyllostomidae). Biotropica 31(2):344-353.

Kronfeld-SCHOR, N. \& DaYAN, T. 2003. Partitioning of time as an ecological resource. Annual Review of Ecology Evolution and Systematics 34:153-181.

Kunz, T. H. \& Fenton, M. B. 2003. Bat Ecology. Chicago, The University of Chicago Press, Chicago.778p.

KunZ, T. H.; Torrez, E. B.; BAUER, D.; Lobova, T. \& Fleming, T. H. 2011. Ecosystem services provided by bats. Annals of New York Academy of Sciences 1223(2011):1-38.

Levin, S. A.; Muller-Landau, H. C.; Nathan, R. \& Chave, J. 2003. The ecology and evolution of seed dispersal: a theoretical perspective. Annual Review of Ecology and Systematics 34:575-604.

Macedo, M. N. C.; Dias, H. C. T.; Coelho, F. M. G.; Araujo, E. A.; SouZA, M. L. H. \& SILVA, E. 2013. Precipitação pluviométrica e vazão da bacia hidrográfica do Riozinho do Rôla, Amazônia Ocidental. Ambi-Agua 8(1):206-221.

Mancina, C. A. \& Castro-Arellano, I. 2013. Unusual temporal niche overlap in a phytophagous bat ensemble of western Cuba. Journal of Tropical Ecology 29(06):511-521.

Mello, M. A. R. 2009. Temporal variation in the organization of a Neotropical assemblage of leaf-nosed bats (Chiroptera: Phyllostomidae). Acta Oecologica 35(2):280-286.

Ortêncio-Filho, H.; Reis, N. R. \& Minte-Vera, C. V. 2010. Time and seasonal patterns of activity of phyllostomid in fragments of a stational semidecidual forest from the Upper Paraná River, Southern Brazil. Brazilian Journal of Biology 70(4):937-945.

OrtÊNCIO-FILHO, H.; LACHER, T. E. \& Rodrigues, L. C. 2014. Seasonal patterns in community composition of bats in forest fragments of the Alto Rio Paraná, southern Brazil. Studies on Neotropical Fauna and Environment. 49(3):169-179.

Pereira, M. J. R.; Marques, J. T. \& Palmeirim, J. M. 2010. Ecological responses of frugivorous bats to seasonal fluctuation in fruit availability in Amazonian forests. Biotropica 42(6):680-687.

Pires, A. S.; Fernandez, F. A. S. \& Barros, C. S. 2006. Vivendo em um mundo em pedaços: efeitos da fragmentação florestal sobre comunidades e populações animais. In: Rocha, C. F. D.; Bergallo, H. G.; SluYs, M. V. \& Alves, M. A. S. eds. Biologia da Conservação. São Carlos, RiMa Editora, p. 231-260.

Presley, S. J.; Willig, M. R.; Castro-Arellano, I. \& Weaver, S. C. 2009. Effects of habitat conversion on temporal activity patterns of phyllostomid bats in lowland Amazonian rain forest. Journal of Mammalogy 90(1):61-71

Reis, N. R.; Peracchi, A. L.; Sekiama, M. L. \& Lima, I. P. 2000. Diversidade de morcegos (Chiroptera, Mammalia) em fragmentos florestais no estado do Paraná, Brasil. Revista Brasileira de Zoologia 17(3):697-704.

Santos, F. G. A.; Calouro, A. M.; Souza, S. F.; Langue, B. M.; Marciente, R.; Faustino, C. L.; Santos, G. J. J. \& Cunha, A. O. 2012. Ectoparasitismo em uma assembleia de morcegos em um fragmento florestal do estado do Acre, Brasil. Acta Veterinaria Brasilica 6(3):211-218.

SCHNITZLER, H. U. \& KalKo, E. K. V. 2001. Echolocation by insect-eating bats. BioScience 51(7):557-569.

Silveira, M. 2005. A floresta aberta com bambu no sudoeste da Amazônia: padrões e processos em múltiplas escalas. Rio Branco, Editora Universidade Federal do Acre. 153p.

Simmons, N. B. 2005. Order Chiroptera. In: Wilson, D.E. \& Reeder, D.M. eds. Mammals Species of the New World: a Taxonomic and Geographic Reference. v.1. Baltimore, Johns Hopkins University Press, p. 312-359.

Simmons, N. B. \& Voss. R. S. 1998. The mammals of Paracou, French Guiana: a Neotropical lowland rainforest fauna Part 1. Bats. Bulletin of the American Museum of Natural History 237:1-219.

Smythe, N. 1986. Competition and Resource Partitioning in the Guild of Neotropical Terrestrial Frugivorous Mammals. Annual Review of Ecology and Systematics 17:169-188.

Thies, W. \& Kalko, E. K. V. 2004. Phenology of neotropical pepper plants (Piperaceae) and their association with their main dispersers, two short-tailed fruit bats, Carollia perspicillata and C. castanea (Phyllostomidae). Oikos 104(2):362-376. 
Thies, W.; Kalko, E. K. V. \& Schnitzler, H. U. 2006. Influence of environment and resource availability on activity patterns of Carollia castanea (Phyllostomidae) in Panamá. Journal of Mammalogy 87(2):331-338

Voigt, C. C. \& Kingston, T. 2016. Bats in the Anthropocene. In: Voigt, C. C. \& Kingston, T. eds. Bats in the Anthropocene: Conservation of Bats in a Changing World. New York, Springer International Publishing, p. 1-9.
WeinbeER, M. \& KalKo, E. K. V. 2004. Morphological characteristics predict alternate foraging strategy and microhabitat selection in the gleaning bat, Lampronycteris brachyotis (Phyllostomidae). Journal of Mammalogy 85(6):1116-1123.

Weinbeer, M.; Meyer, C. F. J. \& Kalko, E. K. V. 2006. Activity pattern of the trawling bat, Macrophylum macrophyllum, in Panamá. Biotropica 38(1):69-76. 